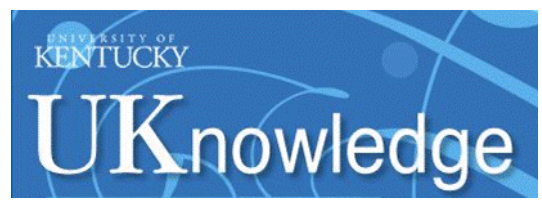

University of Kentucky

UKnowledge

7-8-2014

\title{
The Relationship of CPE to HIV Dementia: Slain by an Ugly Fact?
}

Joseph R. Berger

University of Kentucky, joseph.berger@uky.edu

David B. Clifford

Washington University

Follow this and additional works at: https://uknowledge.uky.edu/neurology_facpub

Part of the Neurology Commons

Right click to open a feedback form in a new tab to let us know how this document benefits you.

\section{Repository Citation}

Berger, Joseph R. and Clifford, David B., "The Relationship of CPE to HIV Dementia: Slain by an Ugly Fact?" (2014). Neurology Faculty Publications. 9.

https://uknowledge.uky.edu/neurology_facpub/9

This Editorial is brought to you for free and open access by the Neurology at UKnowledge. It has been accepted for inclusion in Neurology Faculty Publications by an authorized administrator of UKnowledge. For more information, please contact UKnowledge@lsv.uky.edu. 


\section{The Relationship of CPE to HIV Dementia: Slain by an Ugly Fact?}

Digital Object Identifier (DOI)

http://dx.doi.org/10.1212/WNL.0000000000000580

\section{Notes/Citation Information}

Published in Neurology, v. 83, no. 2, p. 109-110.

(๑) American Academy of Neurology. Unauthorized reproduction of this article is prohibited.

The copyright holders have granted the permission for posting the article here. 


\title{
The relationship of CPE to HIV dementia
}

\author{
Slain by an ugly fact?
}

Joseph R. Berger, MD

David B. Clifford, MD

Correspondence to

Dr. Clifford:

cliffordd@wustl.edu

Neurology ${ }^{\circledR}$ 2014;83:109-110
Thomas Henry Huxley, known as "Darwin's bulldog" for his staunch advocacy of the theory of evolution, is credited with the following statement: "The great tragedy of science-the slaying of a beautiful hypothesis by an ugly fact." The study by Caniglia et al. ${ }^{1}$ in this issue of Neurology ${ }^{\circledR}$ demonstrating that HIV-infected individuals treated with antiretroviral regimens exhibiting better CNS penetration had higher rates of HIV dementia is perhaps the "ugly fact" that might slay a beautiful and widely touted hypothesis. The finding is not only unexpected, but counterintuitive.

The authors analyzed a large dataset comprising nearly 62,000 HIV-infected persons from Europe and the United States and classified them into 3 groups (high, medium, and low) depending on the CNS penetration effectiveness (CPE) of their antiretroviral regimen. Hazard ratios for HIV dementia and several other neurologic complications of AIDS including toxoplasmosis, cryptococcal meningitis, and progressive multifocal leukoencephalopathy were calculated using a pooled logistic regression model for each of the 3 groups. Not surprisingly, the CPE of the antiretroviral regimen did not affect the likelihood of developing AIDS-related CNS opportunistic infections. After all, the predominant driver for the development of these problems is the degree and duration of cellular immunosuppression, not HIV replication in the CNS. Unanticipated was the observation of a direct correlation between high CPE and HIV dementia. The hazard ratio ( $95 \%$ confidence interval) for initiating a combined antiretroviral regimen with a high vs low CPE regimen was $1.74(1.15,2.65)$ for HIV dementia.

The definition of AIDS dementia used in this study, "diagnostic procedures that reflect standard clinical practice in Europe rather than standardized research criteria," was necessarily vague as the data were extracted from clinical records. Because only 235 cases of HIV dementia were identified in more than 60,000 individuals, it is certain that what is reported is vastly different than the prevalent HIVassociated neurocognitive disorder (HAND), a disorder often requiring neuropsychological testing for detection and estimated to occur in 40\%-70\% of HIV-infected individuals. ${ }^{2}$ Because the pathogenic mechanisms underlying subtle neurocognitive abnormalities may not be the same as those responsible for the overt, clinically evident HIV dementia likely represented in this report, ${ }^{3}$ Caniglia et al. can only provide a partial answer regarding the value and risks of CPE-guided combined antiretroviral therapy (cART).

HIV infection of the brain has been strongly implicated as the driver for the development of HIV dementia, although the pathogenesis of the disorder appears to be multifactorial. ${ }^{4} \mathrm{~A}$ high $\mathrm{CPE}$ would be expected to exert maximal benefit on this disorder, rather than increasing the risk as reported. Unexpected outcomes may derive from indirect pathways including the elaboration of neurotoxic cytokines, chronic neuroinflammation, perturbations in cellular channels, oxidative stress, drug toxicity, and alterations in the blood-brain barrier that might each contribute to $\mathrm{HAND}^{5}$; however, many of these mechanisms are the consequence of HIV infection of the cells within the CNS. The authors suggest several potential reasons for their observation: (1) neurotoxicity with deposition of $\beta$-amyloid; (2) poor adherence to the regimen; and (3) the possibility that these regimens were employed in patients already demonstrating neurocognitive abnormalities.

CPE was developed to facilitate study of hypothesized variable cART efficacy in the CNS. ${ }^{6}$ That the brain can represent a distinct viral reservoir is substantiated by multiple cases of CNS "viral escape," where effective control of HIV in the periphery is accompanied by poor viral control in the CNS. ${ }^{7}$ A variety of observations including drug characteristics and clinical evidence were used to suggest the relative effectiveness of individual antiretrovirals for CNS infection, while summing these relative rankings to classify regimens. Importantly, the $\mathrm{CPE}$ ranking does not incorporate any direct evidence of either CNS intracellular drug levels or toxicity. To date, this seemingly rational approach has yielded inconsistent observations with respect to a correlation of CPE and 
neurologic performance measures and no prospective study has yet validated it. ${ }^{8-11}$ Nonetheless, it remains frequently cited as an approach for selecting effective therapy. This study emphasizes that such recommendations are premature. Generally, the most tolerable, potent, and effective cART should be selected, regardless of $\mathrm{CPE}$. In rare instances of viral escape in CSF, selection of cART based on viral resistance of the CSF isolate is necessary.

A dogmatic approach in selecting cART to prevent or treat HAND at the current time seems unwarranted. Further development of ranking schemes for effectiveness in brain may be useful, perhaps including considerations for alternative mechanisms competing with cART efficacy against the virus. The brain is a large potential reservoir for HIV infection and may be responsible for the generation of mutations and resistant HIV strains that reseed the body. Effective treatment of HIV must include controlling HAND and clearing the virus from the brain. More detailed prospective studies, encompassing broader possible mechanisms of action, will be needed to clearly define the risk and benefit of our therapeutic regimens. Meanwhile, it remains remarkable that most cART regimens successfully control the virus when taken faithfully. It would be inappropriate for fear of toxicity to become an excuse for noncompliance with the successful HIV therapies available.

\section{STUDY FUNDING}

No targeted funding reported.

\section{DISCLOSURE}

D. Clifford has served/serves on scientific advisory boards for Amgen, Biogen Idec/Quintiles, BMS, Genentech, Genzyme, Pfizer, Millennium, and Sanofi; received a speaker honorarium from Sun Pharmaceuticals; serves/has served as a consultant for Millennium, Genzyme, Biogen Idec, IAS-USA, CMSC/ACTRIMS, ECTRIMS, Drinker, Biddle, Reath, and Cytheris; receives research support from Lilly, Roche, the NIH (NIMH, NINR), and the Alzheimer Association; and has provided consultation in medico-legal cases. J. Berger has served on scientific advisory boards for
Millenium/Takeda and Amgen; receives honoraria from Genzyme; and has served as a consultant to Millennium/Takeda, Amgen, Genzyme, Eisai, and Novartis. Go to Neurology.org for full disclosures.

\section{REFERENCES}

1. Caniglia EC, Cain LE, Justice A, et al. Antiretroviral penetration into the CNS and incidence of AIDSdefining neurologic conditions. Neurology 2014;83: 134-141.

2. Heaton RK, Clifford DB, Franklin DR Jr, et al. HIVassociated neurocognitive disorders persist in the era of potent antiretroviral therapy: CHARTER Study. Neurology 2010;75:2087-2096.

3. Clifford DB, Ances BM. HIV-associated neurocognitive disorder. Lancet Infect Dis 2013;13:976-986.

4. McArthur JC, McClernon DR, Cronin MF, et al. Relationship between human immunodeficiency virusassociated dementia and viral load in cerebrospinal fluid and brain. Ann Neurol 1997;42:689-698.

5. Buescher JL, Gross S, Gendelman H, Ikezu T. The neuropathogenesis of HIV-1 infection. In: Portegies P, Berger JR, eds. HIV/AIDS and the Nervous System. Amsterdam: Elsevier; 2007:45-68.

6. Letendre S, Marquie-Beck J, Capparelli E, et al. Validation of the CNS Penetration-Effectiveness rank for quantifying antiretroviral penetration into the central nervous system. Arch Neurol 2008;65:65-70.

7. Eden A, Fuchs D, Hagberg L, et al. HIV-1 viral escape in cerebrospinal fluid of subjects on suppressive antiretroviral treatment. J Infect Dis 2010;202:1819-1825.

8. Ellis RJ, Letendre S, Vaida F, et al. Randomized trial of central nervous system-targeted antiretrovirals for HIVassociated neurocognitive disorder. Clin Infect Dis 2014; 58:1015-1022.

9. Simioni S, Cavassini M, Annoni JM, et al. Cognitive dysfunction in HIV patients despite long-standing suppression of viremia. AIDS 2010;24:1243-1250.

10. Marra CM, Zhao Y, Clifford DB, et al. Impact of combination antiretroviral therapy on cerebrospinal fluid HIV RNA and neurocognitive performance. AIDS 2009;23: 1359-1366.

11. Vassallo M, Durant J, Biscay V, et al. Can high central nervous system penetrating antiretroviral regimens protect against the onset of HIV-associated neurocognitive disorders? AIDS 2014;28:493-501. 